\title{
Judeus no Espiritismo e na Umbanda: De entidades a adeptos ${ }^{1}$
}

Alex Minkin ${ }^{a}$

Este artigo busca examinar a interação entre as culturas judaica e brasileira, por meio das lentes do espiritismo e umbanda, bem como as atitudes dos judeus brasileiros para essas religiões. Espíritos judeus de rebeldes, sábios e prostitutas, têm seu lugar particular entre as entidades da umbanda. Nela são encontrados rebeldes judeus que resistiram à opressão das religiões dominantes, os rabinos que invocavam forças místicas da cabala e as prostitutas judias polonesas que ofereciam conselhos sobre assuntos amorosos em iídiche. Cada um desses personagens pode ser atribuído a um contexto histórico específico de imigração judaica para o Brasil: os cristãos-novos portugueses dos séculos XVI e XVII; judeus marroquinos do final do século XIX e os judeus do leste europeu do século XX. $\mathrm{O}$ espiritismo também tem algumas entidades relacionadas com a imigração judaica. Na última parte o artigo examina várias razões pelas quais os judeus brasileiros escolhem praticar espiritismo e umbanda.

Umbanda, Espiritismo, Judaismo.

A estudiosa americana da umbanda, Diana Brown, descobriu uma comunidade única durante sua pesquisa no Rio de Janeiro na década de 1970. O pequeno centro religioso era dedicado ao estudo e interpretação da cabala e composto inteiramente de judeus. $\mathrm{O}$ que

a Pesquisador norte-americano. Email: alex@ticunbrasil.com. 
tornou este centro tão incomum é que os congregantes usavam as práticas de possessão de espíritos da umbanda para promover seus estudos judaicos. Os membros eram possuídos pelos espíritos dos profetas bíblicos e se engajaram em conversas diretas com eles (Brown 1994:135).

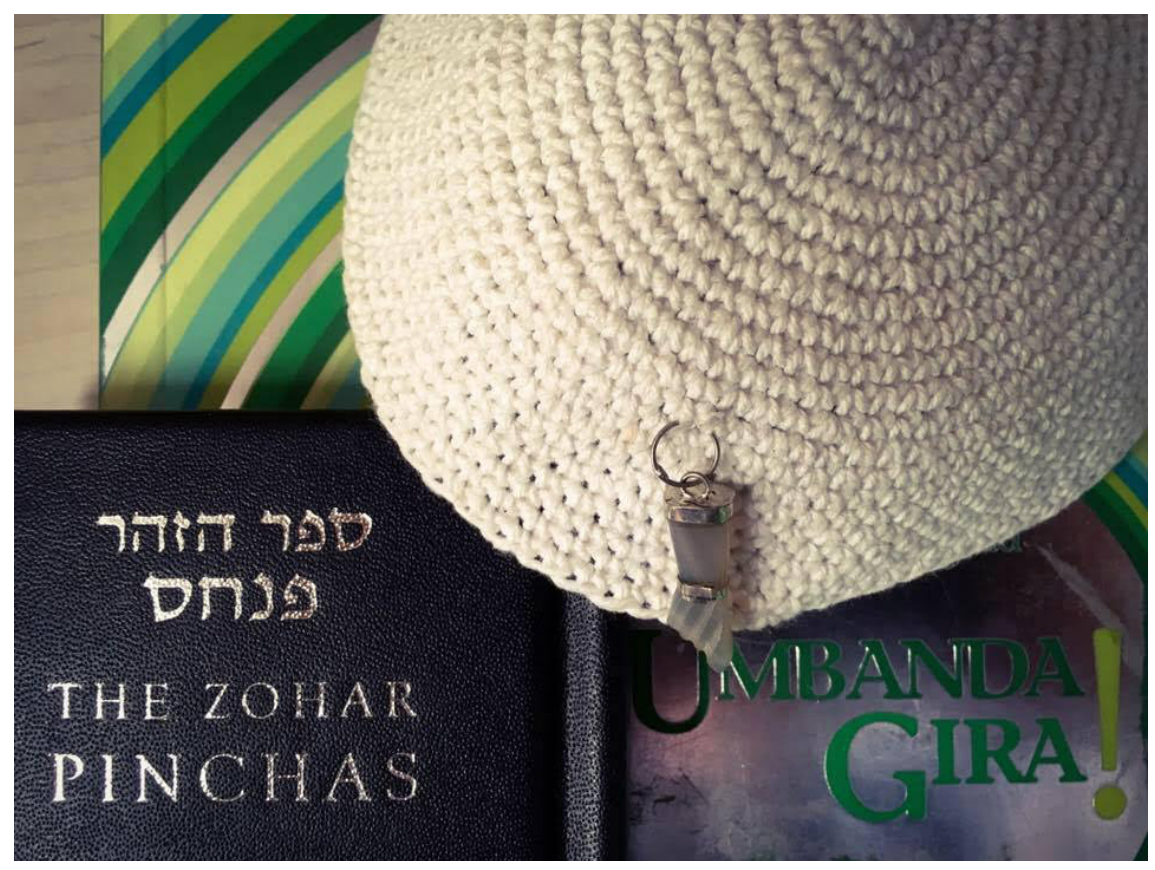

Imagem 1 - Cabala em umbanda. Crédito: Alex Minkin

Muito antes de os judeus começaram a participar de cerimônias espíritas, os temas judaicos influenciavam o misticismo brasileiro. Espíritos judeus de rebeldes, sábios e prostitutas, têm seu lugar entre as entidades do espiritismo e da umbanda. Entre eles haviam alguns rebeldes judeus que recusaram a opressão da religião dominante; os rabinos que invocavam forças místicas da cabala e as prostitutas judias 
polonesas que ofereciam conselhos sobre assuntos amorosos em iídiche. Cada um desses personagens pode ser atribuído a um contexto histórico específico de imigração judaica para o Brasil: os cristãos-novos e o primeiro rabino, judeus marroquinos, rabinos hassídico respeitados por imigrantes judeus da Europa oriental e as prostitutas judias polonesas. $\mathrm{O}$ espiritismo também tem algumas entidades relacionado com a imigração judaica.

O presente artigo vai traçar como os marcos específicos da história judaica brasileira entraram no folclore não judaico brasileiro e como os imigrantes judeus no Brasil se tornaram personagens mitológicos nas cerimônias da umbanda.

Este lado das religiões afro-brasileiras é raramente discutido na academia e até mesmo na teologia da umbanda. A primeira tese sobre espiritismo judaico de Andrea Kogan só saiu em 2016 e não há estudos dedicados aos judeus na umbanda. É importante colocar isso em perspectiva - há poucos espíritos judeus nas religiões afro-brasileiras. Como Francisco Dzialovsky indicado em seu livro O Terceiro Testamento, "é bem verdade que aqui no Brasil não aparecem muitos espíritos judeus. Com esse calor e com essa inflação, e com essa crise qual a alma penada vai baixar por aqui?" (Dzialovsky 1987:89). Apesar de seu número relativamente pequeno, os espíritos judeus oferecem um ângulo único para entender a teologia do espiritismo e da umbanda, bem como a atitude dos judeus na sociedade brasileira. A última parte do artigo examina várias razões pelas quais os judeus brasileiros escolhem praticar espiritismo e umbanda.

\section{Cristãos-novos e o primeiro rabino das Américas}

À medida que o poder e a pressão da inquisição aumentaram em Portugal no século XV, a recém-descoberta terra do Brasil tornouse um dos destinos favoritos dos judeus convertidos ao catolicismo, longe da inquisição. Alguns dos chamados cristãos-novos ainda observavam o judaísmo secretamente. Os cristãos-novos que permane- 
ceram no Brasil foram criados na fé católica e nem eles nem seus pais tiveram contato com a tradição judaica viva. Aqueles que resistiram foram enviados de volta a Portugal para julgamentos de inquisição.

Após 150 anos da conversão forçada, eles se diferenciavam decisivamente do povo judeu, embora algumas características do comportamento judaico possam ter permanecido: casar apenas dentro dos limites de uma comunidade local; doar para caridade; não comer sangue animal; acender velas de Shabat; varrer o chão de uma certa maneira; banhar ritualmente os mortos; deixar pedras nas sepulturas e uma aversão à carne de porco, entre outras coisas.

Recife foi ocupada pelos holandeses em 1624 e assim a próxima onda de imigrantes judeus chegou. A maioria dos habitantes europeus da cidade, após a ocupação holandesa, eram judeus sefarditas, originalmente de Portugal, mas que haviam emigrado primeiro para Amsterdã devido à perseguição da inquisição portuguesa. Eles então ajudaram a colonizar esta nova província holandesa no outro lado do Oceano Atlântico. Naquela época, um proeminente cabalista de Amsterdã, Isaac Aboab da Fonseca, foi nomeado rabino na $1^{\mathrm{a}}$ sinagoga das Américas - Kahal Zur Israel, em Recife. Ainda durante o mandato de Fonseca como rabino em Pernambuco, os portugueses reocuparam a capital do Recife, em 1654, após uma luta de nove anos. Fonseca então retornou a Amsterdã após a perda da nova colônia para os portugueses.

Como veremos, a memória de Fonseca como um poderoso cabalista, bem como o sofrimento e resistência dos cristãos-novos, ainda está viva no misticismo brasileiro de hoje. A ocupação holandesa na região nordeste do Brasil entre 1624 e 1654 serviu como introdução fundamental ao misticismo judaico à população local. A memória das perseguições dos cristãos novos durante a Inquisição portuguesa também se tornou inspiração à literatura brasileira clássica. $\bigcirc$ romantismo no teatro brasileiro começou com a tragédia chamada O Poeta e a Inquisição de Gonçalves Magalhães, publicada em 1838, focada no intelectual brasileiro do século XVIII Antônio José da Silva, apelidado de 'judeu', que foi queimado na fogueira pela inquisição. 
Os judeus caboclos e o santo rabino

A próxima onda de imigração judaica ocorreu em meados do século 19, quando judeus marroquinos estavam fugindo da pobreza, pogroms e perseguições. Por que eles foram para a Amazônia? A explicação para essa imigração teve base legal na lei brasileira de 1814 que abriu os portos brasileiros a todas as nações amigas sem exceção. $\mathrm{O}$ ciclo da borracha (1850-1910) também era muito atraente. Por último, mas não menos importante, os judeus marroquinos se originaram de refugiados espanhóis e portugueses da inquisição que já tinham raízes no Brasil.

No começo, apenas homens jovens, capazes de trabalho manual pesado, vieram para a área. Muitos deles se casaram com mulheres in-

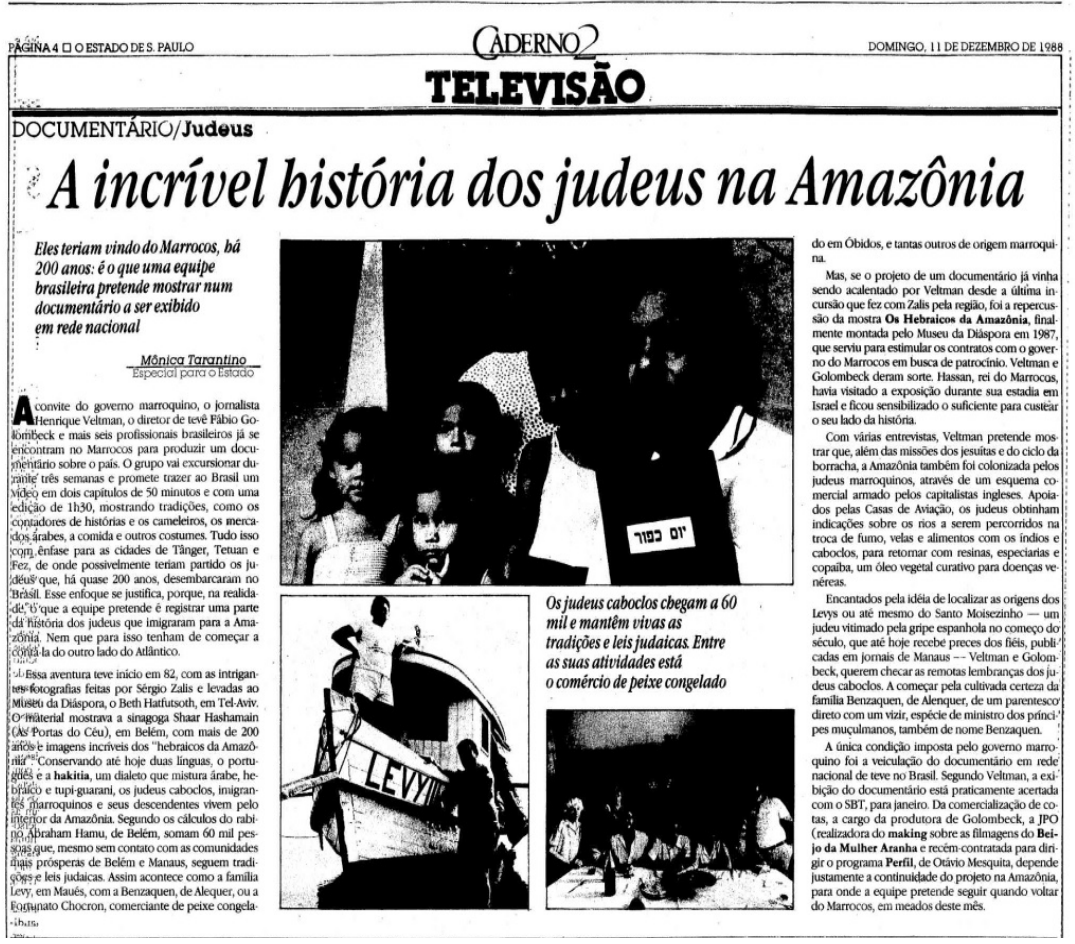

Imagem 2 - Os judeus caboclos. Crédito: O Estado de São Paulo. 
dígenas. Como resultado, a comunidade judaica na Amazônia falava português e um dialeto que mistura a hakitia (língua judaica marroquina, o ladino ocidental) e a língua indígena tupi-guarani. (Tarantino 1988:4).

É nessas famílias mistas que as tradições judaica e indígena tiveram seu primeiro encontro. Rituais de judeus marroquinos caíram no solo fértil no Brasil. Os rabinos eram considerados tzadikim - homens santos, adorados como santos e consultados como trabalhadores de milagres - noção muito semelhante ao catolicismo popular brasileiro e tradição afro-brasileira de cura sagrada.

No antigo cemitério da cidade de Manaus, na Amazônia, há um local de culto para o santo milagreiro judeu que por mais de 100 anos atrai devotos não-judeus brasileiros, seu título é Santo Judeu Milagreiro de Manaus, ou 'Santo Moisézinho'. O rabino Shalom Immanuel Muyal veio do Marrocos no início do século 20 para apoiar uma crescente comunidade judaica. À medida que os judeus marroquinos chegavam à selva, eram inevitavelmente afetados por doenças da floresta, como a febre amarela. Quando o rabino Muyal ficou doente, ninguém o tratava por medo de ficar doente. Porém houve uma pessoa, Cota Israel, que cuidou do rabino até sua morte em 1910. Ele morreu antes da criação do cemitério judeu em Manaus (1928), por isso foi enterrado no cemitério cristão.

No entanto, logo após sua morte, os moradores locais descobriram um fenômeno maravilhoso - Cota Israel, de repente, mostrou uma incrível capacidade de manipular os membros das pessoas e livrá-los de suas tensões e dores. "Onde você conseguiu esse talento maravilhoso?", perguntavam às pessoas. "Rav Shalom Emanuel me deu uma bênção especial antes de sua morte", ela disse: "Eu tenho o poder do rabino, que era um santo", "Agora eu sou capaz de tratar as pessoas por causa dele" (Dahan 2009:180).

Toda vez que uma oração era respondida, a reputação de rabino aumentava. Testemunhos para os poderes de cura do rabino são fornecidas pela quantidade de placas pregadas nos lados de seu túmulo. 
Em 1980 o parente de Muyal tentou carregar os restos mortais do rabino para ser enterrado em Israel, o que causou alvoroço entre os brasileiros, "Estávamos preocupados que, se o levássemos, os cristãos não ficariam loucos, mas um pouco desapontados”, diz Anne Benchimol, líder da comunidade judaica local. "Na época, a comunidade judaica argumentou que o rabino veio para a Amazônia em busca de trabalho e serviço comunitário. Ficando aqui, ele continuou a prestar serviços. Ele é nosso embaixador na comunidade não-judaica em Manaus" (Dahan 2009:189).

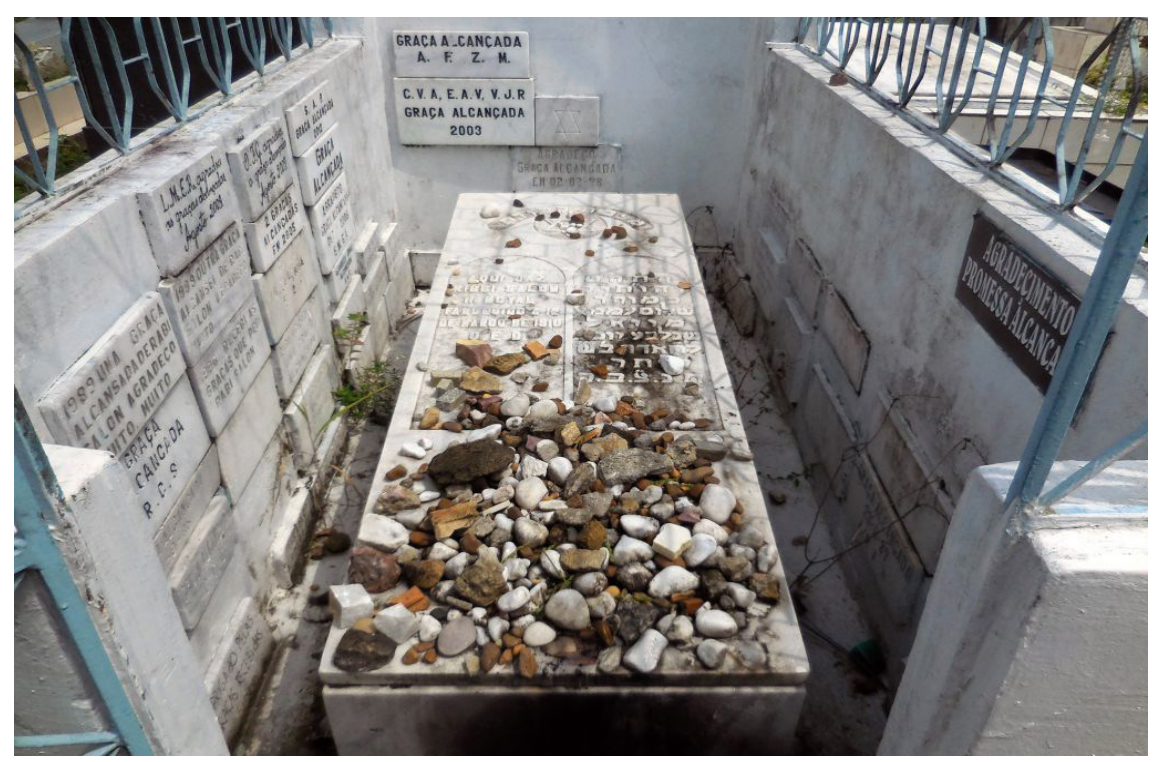

Imagem 3 - Sepultura do rabino Muyal. Crédito: AP/Chris Lehourites.

O povo judeu, de acordo com a tradição, deixa pedras nas sepulturas. Mas lá, os cristãos também são conhecidos por deixar pedras, na esperança de aumentar suas chances de ter um milagre respondido pelo 'santo judeu'. 


\section{'Polacas', as prostitutas judias}

Vários grupos internacionais operaram o auge do comércio sexual de escravos no século XIX. Gangues criminosas traficavam as mulheres de toda a Europa e partes da Ásia. Segundo os historiadores, japoneses e chineses tiveram o maior papel no tráfego mundial. Por quase 80 anos, entre 1860 e 1939, havia uma gangue judia chamada Zwi Migdal que traficava mulheres judias analfabetas dos shtetls da Europa Oriental para o exterior, supostamente para o casamento.

Zwi Migdal foi baseado nos Estados Unidos, Argentina e Brasil. A organização tinha presença controversa na comunidade judaica da América do Sul. Foi uma defensora do teatro iídiche no Brasil, mas foi atacado por judeus no Rio por apresentarem pergaminhos de Torá. Como a maioria das mulheres veio da Polônia, elas eram chamadas de 'polacas' e essa palavra adquiriu um significado desdenhoso no Brasil. Milhares de polacas se mudaram para o Brasil entre 1867 e 1939. Algumas delas ainda eram encontradas em zonas de prostituição até o final dos anos 50. Somando-se à sua miséria, a comunidade judaica brasileira rejeitou as mulheres, tidas como impuras e não permitiu que fossem enterradas nos cemitérios judaicos.

Apesar de sua vida conturbada e desprezo social, essas mulheres nunca se esqueceram de que eram judias. As polacas se uniram para formar suas próprias sociedades benevolentes chamadas Chesed Shel Emes ou Sociedade da Verdadeira Caridade para realizar rituais judaicos e obter um enterro de 3 a classe. Em nenhum outro lugar do mundo, prostitutas, especialmente prostitutas judias, formaram suas próprias organizações religiosas. As polacas tiveram um impacto duradouro na cultura brasileira. A palavra cafetão ou cáften (indivíduo que explora prostitutas) é derivada do caftan, o longo casaco tradicionalmente usado pelos judeus do leste europeu. A palavra encrenca, hoje em dia significando dificuldade ou desordem, derivou do iídiche ein krenk (um doente) e originalmente se referia a um homem com 
doenças venéreas. A palavra sacanagem e derivada do í́diche sacone (ameaça). Como veremos, há também uma conexão mística com as polacas na umbanda. As polacas se misturaram com malandros e boêmios cariocas e serviram como mensageiros involuntários do judaísmo.

\section{Espiritismo e umbanda}

Há uma razão pela qual o Brasil é chamado de 'incubadora de religiões' - existem centenas de misturas e variações compostas de elementos africanos, indígenas e europeus. Neste artigo estou focando em dois movimentos religiosos, espiritismo e umbanda, por 2 motivos: 1 . Ambas religiões estão chamando espíritos judeus; 2. Ambas religiões são populares entre os judeus brasileiros.

O espiritismo, originário da França do século XIX, está agora quase esquecido lá. No Brasil, no entanto, existem entre 20 à 60 milhões de seguidores. Os métodos de comunicação com os espíritos enfatizam racionalidade. Os médiuns nao se consideram 'possuídos por', mas sim 'trabalhando com' os espíritos. No Brasil o espiritismo acrescentou camadas místicas e evoluiu para religião. O número oficial de seguidores da umbanda é de apenas meio milhão. No entanto, muitos ainda têm medo de afirmar que pertencem à religião e dezenas de milhões assistem aos rituais, mas não como fiéis regulares - a maioria dos brasileiros freqüenta para consultas espirituais.

A umbanda surgiu no início do século XX, no mesmo tempo que o samba, co-criando a identidade brasileira baseada na mistura de culturas religiosas africanas, indígenas e européias. A umbanda é baseada na mistura de candomblé (onde a espiritualidade tradicional africana é combinada com o popular catolicismo brasileiro), o espiritismo e elementos nativos romantizados. Pode-se pensar em candomblé como um antigo testamento da umbanda.

$\mathrm{O}$ catolicismo era intolerante tanto às religiões afro-brasileiras quanto ao espiritismo por causa da proibição explícita de consultar os mortos. Pregadores católicos no início do século XX condenaram 
as práticas de cura do candomblé e da umbanda como fraudes. A umbanda tentou apaziguar os cristãos, mantendo os santos católicos para representar a maioria dos orixás e pela desafricanização dos rituais. Não pareceu convencer os católicos - em 1946 a igreja processou a Federação de Umbanda de São Paulo por violações de direitos autorais usando imagens católicas nos rituais. Os católicos viram na umbanda uma ameaça ao monopólio da igreja sobre a revelação religiosa.

Com a falta de autoridade religiosa central eficaz, quase todos os templos individuais da umbanda seguem sua rota teológica única dentro do espectro das umbandas, de modo que alguns estão mais próximos do candomblé, enquanto outros do espiritismo. Os praticantes da umbanda acreditam que um espírito pode ser incorporado ao corpo de um médium - um membro da congregação que comunica entre o mundo dos espíritos e seres humanos vivos - para oferecer consultas espirituais, ou caridade, aos congregados.

\section{Espíritos judaicos no espiritismo e umbanda}

A umbanda foi criada como uma plataforma aberta para qualquer espírito que queira se manifestar com foco nas minorias perseguidas. Embora tenha começado com espíritos de índios e escravos africanos rejeitados em cerimônias kardecistas como de baixo astral, durante os últimos 100 anos ele se transformou no que estudioso de religiões brasileiras Reginaldo Prandi chamou de "palco do Brasil" (Prandi 1991:88).

Existem arquétipos de todos os grupos sociais e personagens folclóricos na umbanda - dos migrantes do Bahia para os aristocratas portugueses; de marinheiros a divindades africanas, de malandros a crianças e ciganos. Nas palavras de Reginaldo Prandi, "a religião sempre é uma renovação de uma história, toda religião começa com uma história que tem alguns personagens, que passam a ter uma importância muito grande, porque são personagens que nós consideramos nossos protetores, nossos criadores, nossos fundadores, nossos guias, 
nossos orientadores. Toda religião começa sempre com uma história que tem personagens que são reverenciados" (2015:4) Personagens judaicos foram também incluídos no panteão da umbanda porque se sabe que eram perseguidos e por causa do apelo místico da cabala. $\mathrm{Na}$ minha pesquisa encontrei vários espíritos judeus em cerimônias de espiritismo e da umbanda.

Há espíritos de caboclos judeus na umbanda do Nordeste do Brasil, como é o caso do caboclo judeu Jaguarema, resistente ao cristianismo. Ele é descrito como forte, corajoso e, às vezes violento, "meiodoido" e cruel. (Ferretti 2000:18). Sulivan Charles Barros também descobriu espíritos semelhantes de exus judeus e marinheiros judeus nas suas pesquisas. (Barros 2013:8) Esses espíritos provavelmente foram inspirados por cristãos novos. Há outra teoria, no entanto, que os espíritos caboclos judeus são uma metáfora abreviada para recusar a conversão ao cristianismo e incluir outros não-cristãos, como muçulmanos e indíenas.

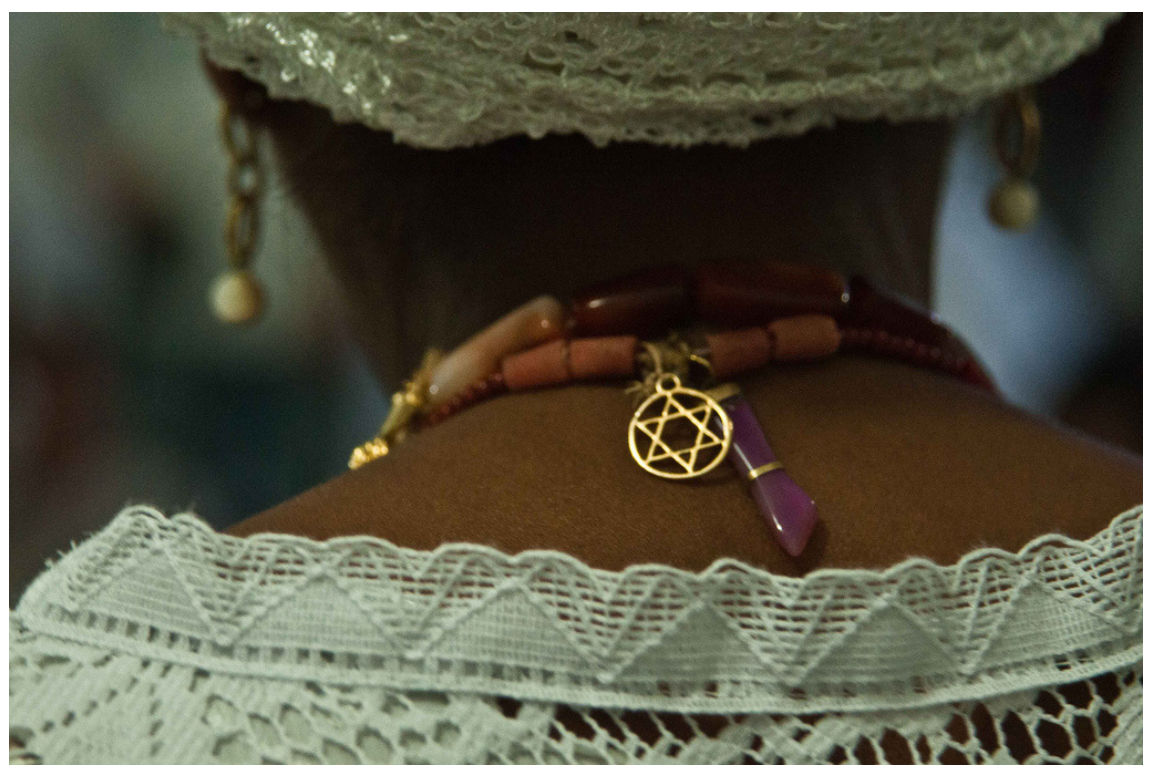

Imagem 4 - Umbanda. Crédito: Bruno Morais 
Hoje há cerimônias regulares nos terreiros de umbanda chamando os espíritos do oriente (Povo do Oriente) que inclui cabalistas e rabinos, juntamente com outros sábios orientais. Esses espíritos são chamados cantando hinos em hebraico. Durante as décadas de 1960 e 1970 do oriente abarcando várias religiões de imigrantes para o Brasil do budismo ao islamismo e judaísmo. Às vezes espíritos orientais aparecem nas cerimônias dos ciganos em umbanda.

Espíritos cabalísticos 'elevados' (usando o termo espírita) de rabinos, como Santo Moisézinho e Isaac Aboab da Fonseca, ocupam um lugar especial no espiritismo e na umbanda, invocando forças místicas de cabalá para curas e consultas espirituais. Pai Jacó do Oriente é escravo africano bem versado em cabala que aprendeu com seu mestre.

Finalmente, há uma figura de polaca na umbanda. Sendo uma prostituta em sua vida terrena, ela pertence ao arquétipo da umbanda chamado pomba gira. Espíritos de polacas são retratados como mulheres bonitas que falam sobre o sofrimento em sua vida terrena por causa da escravidão sexual. Esses espíritos retornam à terra para os templos de umbanda como conselheiros em questões de amor, uma inversão simbólica quando os oprimidos se tornam divindades. Há uma vingança simbólica no retorno da polaca, assim como com os espíritos dos indígenas e dos escravos, a umbanda está tentando reparar os danos históricos, capacitar os excluídos com força espiritual.

Não há evidências de que as próprias polacas participavam de cerimônias de umbanda, enquanto tentavam manter as tradições judaicas. No entanto, elas foram rejeitadas pela comunidade judaica dominante, enquanto os boêmios não-judeus eram simpáticos ou pelo menos curiosos sobre os rituais místicos das polacas. Na época em que a umbanda foi formada, no início do século XX, os sofrimentos das polacas combinados com suas devoções ao judaísmo fizeram delas figuras de santas no panteão da nova religião. 


\section{Judeus brasileiros: de rejeição do carnaval ao Shabat no terreiro}

A falta de antissemitismo e a sociabilidade dos brasileiros levam à imersão em todas as facetas da cultura brasileira, do carnaval à religião. A integração à sociedade pode ser rastreada ao longo das atitudes em mudança para o carnaval. No início, o feriado foi visto como uma festa de rua pagã selvagem que afastou os judeus tradicionais da Europa Oriental. É assim que tais atitudes podem ser vistas no livro didático para a escola de crianças judias de 1934 em iídiche de São Paulo: "Yidele não observa carnaval. Yidele ri das crianças judias que dançam no carnaval. Yidele é um garoto inteligente, ele diz a todos - o carnaval não é judeu" (Iddiche Kinder 1934:40)2.

Poucas décadas depois, em 1974, Henry Sobel o rabino chefe do judaísmo reformista de São Paulo observou que "podemos aprender uma lição do carnaval carioca. Muitos judeus são apenas observadores passivos dos rituais da sinagoga. Isto é o que precisamos aplicar em nossa consciência religiosa hoje: mais devoção e alegria na observância" (Sobel 1974:20). Nas últimas décadas, os judeus começaram a abraçar ativamente a oportunidade de mostrar as tradições de sua comunidade aos seus compatriotas no carnaval. Diversos ensaios do carnaval em temas judaicos foram produzidos com consulta e participação da comunidade judaica. Atitudes para com as religiões brasileiras também mudaram; os judeus participam de rituais kardecistas e de umbanda, ou até mesmo formam seus próprios templos espíritas.

Mendel, personagem principal do romance do escritor judeu brasileiro Mauricio Wrots Moishele e a roseira sem flor, é um tradicional judeu que emigrou para o Brasil da Polônia, na primeira metade do século XX. Lá ele prospera e contrata uma secretária negra Vicentina, que por acaso é uma médium da umbanda. "Mendel respeitou as crenças dos ex-escravos e ficou encantado com a sutileza dos orixás... A cabalá nos ensina a não desprezar certos sinais, certos avisos, não importa de onde eles vêm ... A mensagem cabalística pode vir de uma criatura humilde de credo esotérico" (Wrots, 2014:65). Wrots descreve como Mendel "viveu informado sobre a umbanda e soube de vários 
judeus que frequentavam terreiros". No terreiro, Mendel se encontra com o pai de santo em transe, incorporado ao espírito do pai de Mendel e falando em iídiche (Wrots 2014:77).

O autor judeu brasileiro Francisco Dzialovsky coloca esta questão em sua obra satírica O Terceiro Testamento: "Assim não haverá nada de estranho, se o judaísmo brasileiro absorver por completo o culto aos orixás. Se a umbanda tem a grandeza de pegar para si rituais indígenas, africanos, católicos, espíritas etc., por que teremos que ficar atrás? As outras religiões necessitam se abrir para não perecer, pois sabemos que é muito maior o número de católicos nos terreiros que na igreja, e muito maior o número de judeus fazendo despachos nas esquinas do que acendendo as velas de Shabat" (Dzialovsky 1987:147). O autor está, é claro, exagerando, mas há, de fato, um número significativo de judeus brasileiros presentes em reuniões kardecistas e rituais de umbanda.

Uma boa indicação da integração dos judeus no espiritismo brasileiro é o livro mediúnico do líder espírita brasileiro Chico Xavier,

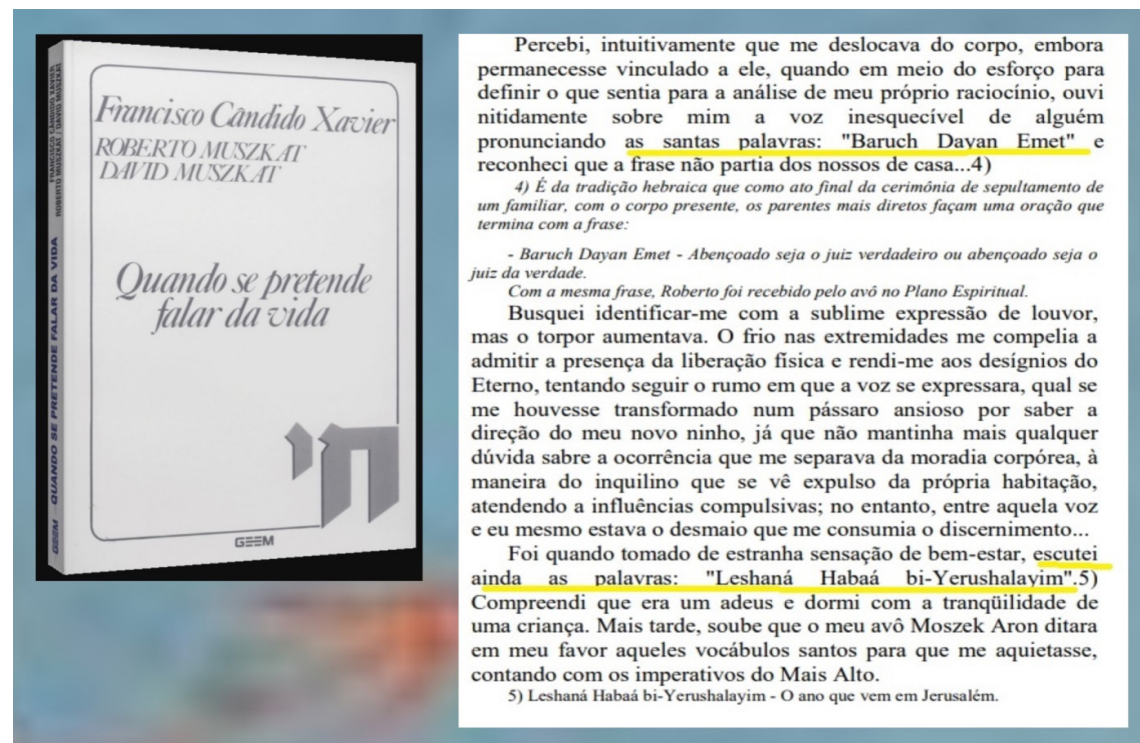

Imagem 5 - Chico Xavier. Quando Se Pretende Falar da Vida. São Paulo, Editora Geen. 
chamado Quando Se Pretende Falar Da Vida. Estas cartas psicografadas apresentam comunicação com o "valoroso jovem de formação israelita, Roberto Muszkat” (Xavier 1984:28). Chico Xavier aqui dá conta muito detalhada da vida judaica cheia de referências à tradição judaica, festas e objetos sagrados.

Este artigo começa com uma referência à pesquisa de Diana Brown, onde ela descreve o centro de umbanda judaica no Rio de Janeiro. Quando entrevistei Reginaldo Prandi para este artigo em abril de 2018, ele relembrou a visita ao terreiro de umbanda em São Paulo na década de 1980. O pai de santo e muitos dos congregantes eram judeus e o centro tinha cerimônias regulares de Shabat judaico (não misturado com rituais de umbanda). Prandi sugeriu que o ritual se sentia no lugar, uma vez que a umbanda enfatizava a abertura e a tolerância a outras religiões (Prandi 2018:7).

Em 1987 o rabino Zalman Schachter Shalomi, fundador do movimento de renovação judaica, encontrou-se com mãe Beata, a mãe de santo de mais de um milhão de pessoas no Rio de Janeiro. É assim que o rabino liberal do Rio de Janeiro Nilton Bonder se lembra daquela reunião, "Eles começaram a se comunicar em uma linguagem não convencional, uma espécie de linguagem de sinais espirituais. Em algum momento, mãe Beata pediu a Zalman que a abençoasse" (Bonder 2014:8). Desde então os líderes religiosos judeus liberais entram no diálogo com as comunidades afro-brasileiros.

Pesquisadora Andréa Kogan fez doutorado em 2016 sobre espiritismo judaico em São Paulo descrevendo as reuniões em casas de judeus espíritas em São Paulo em década 2010. As entidades, como conhecem as pessoas ali presentes e sabem que a maioria é judia fazem algumas ligações com o mundo judaico. Por exemplo, em uma determinada ocasião uma entidade falou: "Ah, este mês é muito importante para vocês, nós sabemos". Era o mês do ano novo judaico (Rosh Hashaná) e na sequência o Dia do Perdão (Yom Kippur). Em uma das sessões o rabino foi incorporado e informou que era o Rebbe Yaakov. Este falou uma ou outra palavra em hebraico enquanto dava bênçãos 
(como se fossem passes) aos presentes. Ao final, disse a palavra shalom, que quer dizer paz e é usada em comprimentos gerais (como olá e tchau). Em outras sessões a entidade foi perguntada seu nome e respondeu: "Rebbe Moishe, 1893, hassídico Lubavich, da Roménia" (Kogan 2016:19).

\section{Por que os judeus brasileiros se voltam para o espiritismo e a umbanda?}

Primeiro de tudo, vamos colocar isso em perspectiva. Assim como há poucos espíritos judeus na umbanda e no espiritismo, um número relativamente pequeno (embora não haja estatísticas disponíveis) de judeus brasileiros participa das cerimônias. Nós certamente precisamos excluir aproximadamente $10 \%$ dos judeus brasileiros que são ortodoxos e vê o espiritualismo como avodah zarah (idolatria) e também levar a proibição da comunicação com os mortos a sério. Muitos judeus percebiam o judaísmo formal tradicional como seco, cheio de observâncias técnicas e falta de espiritualidade. Para eles, o espiritismo/a umbanda ligou os pontos em termos de como passar da transformação desejante da consciência para uma experiência real de transformação. Os judeus se voltaram para o espiritismo e a umbanda como uma forma brasileira de contracultura, assim como judeus europeus e norte-americanos exploraram o budismo, ou religiões da nova era nos anos 60. Para ser justo, isto não é porque no judaísmo está faltando misticismo, mas porque não é tão facilmente acessivel como em outras religiões.

Para a maioria dos judeus que frequentam os centros espíritas e os terreiros, o espiritismo e a umbanda não são umas religiões primárias, mas sim umas camadas místicas, perdendo a dimensão espiritual de sua $1^{\text {a }}$ religião. Para tais judeus, desde que seja permitido preservar a religião primária, se pode ter raizes judaicas e asas espiritas. Apropriadamente para o cidadão urbano moderno, umbanda tem foco no retorno à natureza. Há uma noção central de caridade no espiritismo e na umbanda, da mesma forma que o judaísmo. Os espíritos da 
umbanda são almas imperfeitas, esses espíritos são libertadores e não julgadores. Eles entendem os problemas dos homens comuns e tentam evoluir ajudando-os. O judaísmo já tem conceito de incorporação (dibbukim), mas não é central para a religião. No início, os judeus se voltaram para o espiritismo, considerado da classe média alta e mais sofisticado, mais tarde a umbanda, considerada democrática, tornouse a forma mais comum de contra-cultura. Alguns percebem o judaísmo como 'elitista' ou 'de direita', enquanto a umbanda é percebida pela algumas como democrática, inclusiva e popular, com rituais mágicos, interativos e musicais.

Os judeus brasileiros que praticam o espiritismo e a umbanda estão se comunicando principalmente com espíritos não-judeus. Os respondentes da minha pesquisa desenvolveram uma interpretação judaica da umbanda de evitar referências cristãs ao se reunir com outros judeus. Nas últimas décadas houve um processo de africanização da umbanda, com a correspondente remoção de referências cristãs. Mesmo antes disso, alguns judeus aprenderam a desconsiderar os componentes cristãos e se concentrar na mensagem universal da umbanda.

Padrinho Jonathan Goldman, um judeu que se tornou um dos líderes do movimento umbandaime, relembra sua experiência: "O primeiro ritual que eu assisti foi uma sessão de dança e canto de 200 pessoas no topo de uma montanha em um vale remoto no Brasil. Junto com a força do daime, encontrei-me em um forte estado alterado na presença desta grande cruz no meio do altar. Comecei a ter pensamentos sobre os massacres que meus ancestrais judeus russos tinham passado, e foi como 'Nossa! Aqui estou neste lugar totalmente bizarro e eles vão me matar'. Eu estava experimentando o que o rabino Zalman Schachter chama de Perturbação de Stresse Pós-Traumático Judaico (PSPTJ). É profundo e por um bom motivo fiquei me perguntando: 'O que estou fazendo aqui?' A combinação do PSPTJ e daime me fez querer fugir. Depois de um tempo, consegui me concentrar e então vi que a cruz no altar estava na base de uma estrela de seis pontas. Eu olhei para a estrela e disse para mim mesmo: 'A estrela com a qual eu 
posso lidar. Eu vou ignorar a cruz, então eu não corro para fora daqui gritando"” (Levin 2015:78).

Há uma diferença fundamental entre as culturas brasileira e judaica. Segundo Bernardo Sorj, "enquanto a cultura brasileira cultiva o esquecimento, a cultura judaica se sustenta na lembrança. A cultura judaica é uma cultura de angústia. Angústia implica insatisfação com o presente, vontade de mudar, enquanto a cultura popular brasileira enfatiza o 'deixa pra lá', viver o presente e esperar que surjam dias melhores" (Sorj 2008:157). Enquanto o judaísmo se constitui numa atitude de 'voluntarismo pessimista', a cultura brasileira é de um 'fatalismo otimista', excelente antídoto para a depressão. A convivência da mitologia judaica e brasileira não deixa de ser altamente terapêutica para os judeus. Sorj conclui que o judaísmo brasileiro, apesar de seu número limitado, tem um potencial de fontes renováveis de recuperação da mitologia e tradições judaicas dentro de um espírito de diálogo, confrades e quase falta de antissemitismo.

No outono de 2015 eu participei de um ritual alegre, criativo e poderoso. Um casal judeu escolheu um pequeno terreiro de umbanda em uma favela do Rio de Janeiro para o ritual de casamento. Eles

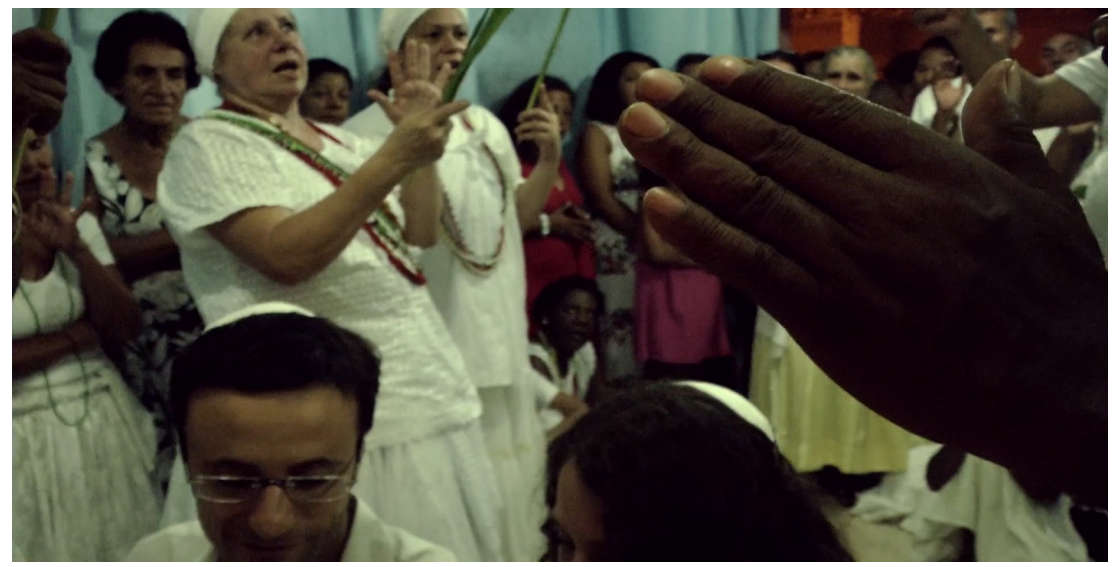

Imagem 6 - Casamento judaico em umbanda. crédito da imagem: Vincent Moon. 2018. 'Centro de umbanda. caboclo sete flechas (casamento)'. Híbridos os espíritos do Brasil, hibridos. 
participaram de uma cerimônia que mesclou a tradição judaica de lembrar a destruição do templo de Jerusalém quebrando um copo e, ao mesmo tempo, invocando espíritos da floresta e do mar para receber suas bênçãos. Eu considero o rito como um símbolo de coexistência entre judaísmo e umbanda e busca conjunta pela espiritualidade.

\section{Notas}

1 Alex Minkin é pesquisador norte-americano dedicado à investigação sobre a interação entre culturas judaica e brasileira no contexto do espiritismo e umbanda, e a participação de judeus brasileiros nessas religiões. Ministrou cursos e palestras sobre o tema nos Estados Unidos e Brasil (New York Public Library, Brazilian Endowment, Midrash Rio, UFSC, UFPE, UFS, etc.). Possui artigos publicados no Forward, Sounds and Colours, Jewish Currents. Originalmente de Moscou, Alex é fundador da Ticún Brasil (2008), uma inovadora ONG que implementa projetos educacionais, sociais e culturais no Rio de Janeiro, bem como difusão da cultura brasileira em Nova York. O texto do artigo refere-se a uma conferencia que o mesmo ministrou no PPGA em 11 de abril de 2018.

2 Iddiche Kinder, livro didático para a escola de crianças judias em iídiche, publicado em 1934. São Paulo. Cortesia de YIVO (New York).

\section{Referências}

BARROS, Sulivan Charles. 2013. As entidades 'brasileiras' da umbanda e as faces inconfessas do Brasil. Trabalho apresentado no XXVII Simpósio Nacional de Historia, ANPUH, Natal-RN.

BONDER, Nilton. 2014. Rabbi Nilton Bonder Remembers Zalman Schachter Shalomi. Berkeley: Tikkun Magazine.

BROWN, Diana. 1994. Umbanda: Religion and Politics in Urban Brazil. New York/ Columbia: University Press.

DAHAN, Isaac. 2009. Or Gadol. São Paulo: Editora Sefer.

DZIALOVSKY, Francisco. 1987. O Terceiro Testamento. São Paulo: Anima.

FERRETTI, Mundicarmo. 2000. Desceu na Guma: o caboclo do Tambor de Mina em um terreiro de São Luis, a Casa Fanti-Ashanti. São Luís: EDUFITIA.

KOGAN, Andrea. 2016. Vivência espiritual judaica na metrópole paulistana: judeusespíritas na contemporaneidade. Tese de Doutorado. São Paulo: PUC. 
LEVIN, Alan. 2015. Crossing the Boundary: Stories of Jewish Leaders of Other Spiritual Paths. Berkeley: Regent Press.

PRANDI, Reginaldo. 1991. Os candomblés de São Paulo. São Paulo, Hucitec.

PRANDI, Reginaldo.. 2015. Palauras. Híbridos os espíritos do Brasil, hibridos. [Manuscrito]. . 2018. Entrevista a Alex Minkin. [Manuscrito].

SOBEL, Henry I. Judaísmo é Otimismo. 1974. São Paulo, Perspectiva.

SORJ, Bernardo. 2008. "Brazilian Non-anti-Semite Sociability and Jewish Identity". Identities in an Era of Globalization and Multiculturalism. Latin America in the Jewish World, 8: 151-169

TARANTINO, Monica. 1988. "A incrivel história dos judeus na Amazonia”. O Estado de São Paulo, publicado em 12/11/1988:4.

WROTS, Mauricio. 2014. Moishele e a roseira sem flor. Greenville: KBR.

XAVIER, Francisco C. 1984. Quando Se Pretende Falar da Vida. São Paulo: Editora Geen.

Abstract: This article explores the interaction of Jewish and Brazilian cultures through the centuries, focusing on Jewish themes in Brazilian religions of Kardecism and Umbanda. Several waves of Jewish immigration to Brazil are considered: from Portuguese crypto-Jews of 16th and 17th centuries and Moroccan Jewish Amazon rubber boom workers of late 19th century, to Eastern European immigrants of the 20th century. Each of these waves influenced Umbanda, a syncretic Afro-Brazilian religion that celebrates, among others, the spirits of Jewish rebels, sages and prostitutes. Finally, the changing attitudes of Brazilian Jews towards both religions are analyzed.

Keywords: Judaism, Kardecism, Umbanda.

Recebido em setembro de 2018. Aprovado em dezembro de 2018. 